\title{
EKTRAKSI FITUR MENGGUNAKAN DISCRETE WAVELET TRANSFORM DAN FULL NEIGHBOUR LOCAL BINARY PATTERN UNTUK KLASIFIKASI MAMMOGRAM
}

\author{
Januar Adi Putra ${ }^{1}$, Nanik Suciati ${ }^{2}$, Arya Yudhi Wijaya ${ }^{3}$ \\ Jurusan Teknik Informatika, Fakultas Teknologi Informasi, \\ Institut Teknologi Sepuluh Nopember (ITS) \\ Email: januaradi.putra@gmail.com ${ }^{1}$,naniksuciati@gmail.com², arya@cs.its.ac.id ${ }^{3}$
}

\begin{abstract}
Abstrak
Local binary pattern adalah sebuah kode biner yang menggambarkan pola tekstur lokal. Hal ini dibangun dengan lingkungan batas dengan nilai abuabu dari pusatnya. Local binary pattern tradisional memiliki beberapa kelemahan yakni varian terhadap rotasi dan pada saat proses thresholding pixel sensitif terhadap noise. Pada penelitian ini diusulkan sebuah metode ektraksi fitur baru untuk mengatasi masalah tersebut, metode tersebut disebut full neighbour local binary pattern (fnlbp). Metode ini nantinya akan dikombinasikan dengan discrete wavelet transform untuk ektraksi fitur dari citra mammogram dengan metode klasifikasi adalah Backpropagation Neural Network (BPNN). Berdasar ujicoba yang telah dilakukan metode usulan mendapatkan rata-rata akurasi yang lebih baik daripada metode local binary pattern tradisional baik yang dikombinasi dengan discrete wavelet transform ataupun tidak. Performa metode usulan full neighbour local binary pattern dapat menghasilkan akurasi yang sempurna yakni $100 \%$ baik pada saat menggunakan discrete wavelet transform ataupun tidak, sedangkan akurasi terendah yang didapat adalah $90.49 \%$.
\end{abstract}

Kata Kunci: Ekstraksi fitur, local binary pattern, wavelet, klasifikasi mammogram.

\begin{abstract}
Traditional local binary pattern have some disadvantages which is a variant of the rotation and during the thresholding process the pixel is sensitive to noise. At this study the authors proposed a new method of features extraction to solve that problem and this method called full neighbor local binary pattern (fnlbp). This method will be combined with discrete wavelet transform to extract the features of
\end{abstract}

the mammogram image and the classification method is Backpro- pagation Neural Network (BPNN). Based on experiments the result of proposed method in an average accuracy is better than traditional methods of local binary pattern which combined with discrete wavelet transform or not. The performance of the proposed method of full neighbor local binary pattern can produce perfect accuracy that is $100 \%$, this accuracy is reached when using discrete wavelet transform or not, while the lowest accuracy obtained is $90.49 \%$.

Keywords: News document, categorization, multilabel, Ontology, domain-specific.

\section{Pendahuluan}

Salah satu metode yang paling efektif untuk mendeteksi dan mengidentifikasi kanker payudara adalah melalui pemeriksaan mammografi dengan menggunakan sinar $\mathrm{X}$. Citra yang dihasilkan dari sinar X tersebut disebut mammogram. Analisa terhadap citra mammografi yang sebelumnya dilakukan oleh radiologis secara manual dapat digantikan dengan teknologi terbarukan dengan memanfaatkan pengolahan citra digital, sehingga hasil yang didapatkan tidak lagi bersifat subyektif dan dapat mengatasi radiologis yang merasa tidak yakin dengan hasil analisanya (Uyun \& Harjoko, 2011).

Terdapat beberapa penelitian yang telah dilakukan sebelumnya dengan memanfaatkan pengolahan citra digital, yaitu analisa multiresolusi berbasis wavelet. Dhawan dkk (1996) menggunakan wavelet decomposition pada citra gray-level untuk klasifikasi citra mammogram dan diperoleh nilai akurasi $81 \%$. Liu dkk (2001) menggunakan fitur statistik berbasis wavelet dan binary tree sebagai classifier mendapatkan akurasi $84.2 \%$ pada

Januar Adi Putra, Nanik Suciati, Arya Yudhi Wijaya

Jurnal Ilmiah Teknologi Informasi Terapan

Volume III, No 2, 15 April 2017 
klasifikasi mammogram. Rashed dkk (2007) menggunakan beberapa tipe Daubechies wavelets pada klasifikasi mammogram, diperoleh akurasi klasifikasi $87.06 \%$. Buciu dkk (2011) menggunakan filter gabor berbasis wavelet untuk fitur ekstraksi, PCA untuk fitur seleksi (dimension reduction) dan support vector machine sebagai classifier untuk mengklasifikasikan citra mammogram sebagai normal-abnormal (performa klasifikasi 79\%) dan benign-malignant (performa klasifikasi 78\%). Sanae dkk (2015) menggunakan wavelet decomposition pada citra mammogram dan dikombinasikan dengan ektraksi fitur local binary pattern mendapatkan akurasi klasifikasi sebesar 93\%. Berdasar hasil studi literatur yang dilakukan, dapat terlihat kombinasi wavelet dengan teknik pengolah citra yang lain menghasilkan akurasi yang cukup tinggi dimana kombinasi wavelet dan local binary pattern merupakan kombinasi yang terbaik.

Saat ini pengembangan algoritma local binary pattern telah banyak dilakukan, Kaya dkk (2015) mengusulkan dua pengembangan baru dari local binary pattern yakni neighbour local binary pattern (nlbp) dan directional binary pattern (dlbp). Dua metode baru tersebut memiliki perbedaan pada arah dan distribusi relasi spasial dari pixel. Pada neighbour local binary pattern histogram dibentuk dengan membandingkan pixel-pixel yang ada diantara pixel tengah, sedangkan pada directional binary pattern histogram dibentuk dengan membandingkan pixel tengah dengan pixel yang ada pada arah yang telah ditentukan. Dua metode pengembangan local binary pattern tersebut telah diuji dengan berbagai citra tekstur dengan classifier adalah Artificial Neural Network (ANN). Dari hasil uji yang telah dilakukan terbukti dua metode pengembangan tersebut menghasilkan akurasi yang lebih baik dari local binary pattern yang tradisional. Meski menghasilkan akurasi yang baik dua metode baru tersebut memiliki beberapa kelemahan yang sama dengan local binary pattern tradisional, yakni histogram yang dihasilkan sensitiv terhadap rotasi dan pada proses thresholding pixel sensitif terhadap noise.

Berdasar uraian yang telah dijelaskan sebelumnya, penelitian ini mengusulkan sebuah metode ektraksi fitur baru yang didasarkan pada neighbour local binary pattern (nlbp). Metode ini memiliki perbedaan pada arah dan distribusi relasi spasial dari pixel, dimana perbandingan antar pixel pada proses trhesholding tidak hanya dengan tetangga di bagian kanan saja melainkan dengan semua tetangga yang ada pada sisi horizontal, vertical dan diagonal sehingga metode tersebut disebut full neighbour local binary pattern (fnlbp). Dengan melakukan perbandingan pixel dengan semua tetangga maka proses thresholding akan lebih insensitif terhadap noise yang akan menyebabkan proses thresholding tersebut lebih akurat dan akurasipun akan meningkat. Metode ini nantinya akan dikombinasikan dengan discrete wavelet transform untuk ektraksi fitur dari citra mammogram dengan classifier adalah Backpropagation Neural Network (BPNN).

\section{KAJIAN LITERATUR}

\section{II.1 Kanker Payudara}

Terdapat beberapa cara untuk mendeteksi dini kanker payudara, salah satunya adalah mendeteksi dan mengidentifikasi melalui pemeriksaan sinar $\mathrm{x}$. Citra yang dihasilkan dari sinar $\mathrm{x}$ tersebut disebut mammogram. Citra mammogram hasil sinar $\mathrm{x}$ dapat dilihat pada Gambar 1.

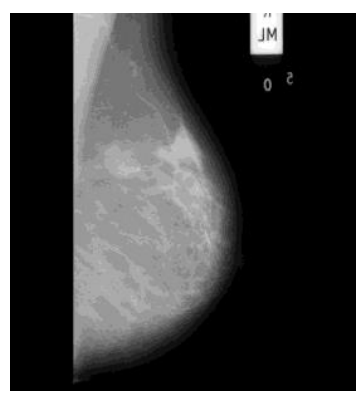

Gambar 1. Citra mammogram

\section{II.2 Local Binary Pattern}

Secara sederhana, LBP adalah sebuah kode biner yang menggambarkan pola tekstur lokal. Hal ini dibangun dengan lingkungan batas dengan nilai abu-abu dari pusatnya (Ahonen, Hadid, \& Pietikainen, 2004).

\section{II.3 Neighbour Local Binary Pattern}

Deskriptor pada metode ini tergantung pada hubungan 8 tetangga, $\mathrm{P}=\{\mathrm{P} 0, \mathrm{P} 1, \mathrm{P} 2, \mathrm{P} 3, \mathrm{P} 4, \mathrm{P} 5$, P6, P7 \}, dengan satu sama lain, sekitar pixel. Dalam proses perbandingannya, nilai setiap pixel tetangga tertentu dibandingkan dengan pixel sebelahnya untuk menentukan thresholding bernilai 1 atau 0 , sedangkan proses-proses selanjutnya sama seperti LBP tradisional. Selain itu, pada nLBP perbandingan 
dapat dilakukan tidak hanya dengan tetangga berurutan akan tetapi dapat juga dilakukan dalam tetangga yang didefinisikan oleh parameter jarak, $d$. Proses perbandingan tersebut dapat dilihat pada Gambar 2.

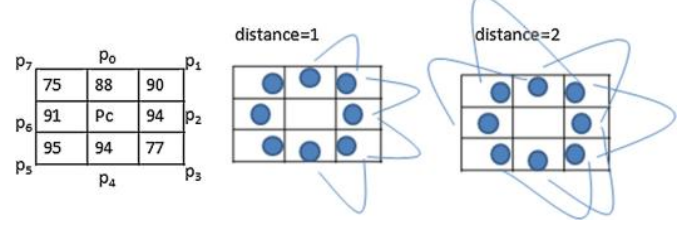

Gambar 2. Proses perbandingan pixel pada nlbp.

\section{Metode Penelitian}

Pada bab ini memaparkan tentang metodologi penelitian yang digunakan pada penelitian ini serta kontribusi dari yang diajukan. Ilustrasi alur metodologi penelitian dan kontribusi dapat dilihat pada Gambar 3.

\section{III.1 Deteksi dan Pemotongan ROI}

Pada mammogram bagian yang paling merepresentasikan kanker adalah region yang mengandung mass sehingga sebelum klasifikasi dilakukan maka citra mammogram akan di preprocessing untuk mendeteksi letak mass tersebut. Contoh ROI pada citra mammogram ditunjukkan Gambar 4. Ada beberapa tahapan dalam mendeteksi dan segmentasi ROI pada citra mammogram. Tujuan dari tahap ini adalah mendapatkan titik kanker pada citra mammogram (mass) yang dapat mengindikasikan seseorang mengidap kanker payudara atau tidak. Tahapan dari deteksi dan segmentasi mass tersebut dapat dilihat pada Gambar 5. Tahapantahapan akan dijelaskan secara terperinci pada subbab berikutnya.

\subsubsection{Penghapusan Black Margin}

Proses Tahap ini merupakan tahap untuk menghilangkan pinggiran hitam pada citra mammogram. Frame hitam pada pinggiran citra harus dihilangkan untuk mempermudah pada proses segmentasi.

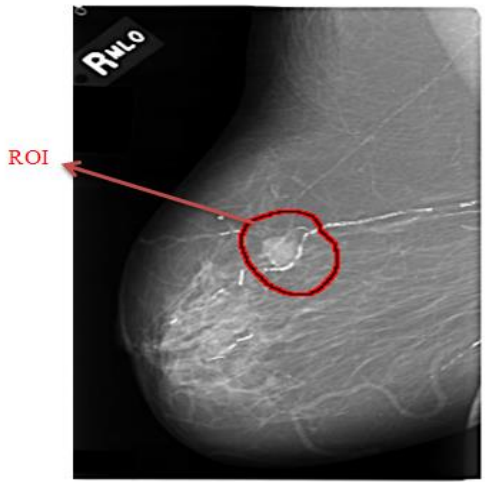

Gambar 4. ROI citra mammogram.

Proses penghapusan black margin dapat dilihat pada Gambar 6. Ada tiga tahapan utama dalam penghapusan black margin ini yakni:

1. Mencari posisi pixel pertama yang tidak berwarna hitam pada posisi horizontal.

2. Mencari posisi pixel terakhir yang tidak berwarna hitam pada posisi horizontal.

3. Memotong citra diantara posisi 1 dan 2 yang telah didapat.
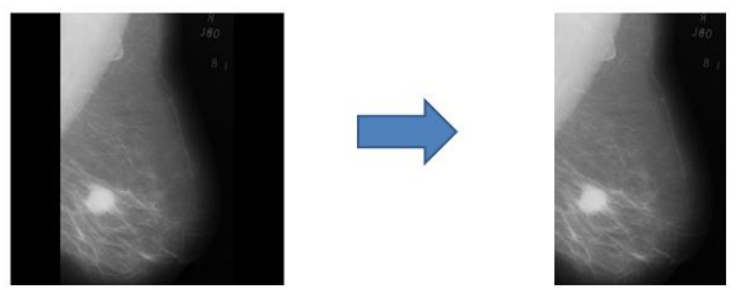

Gambar 6. Penghapusan frame hitam.

\subsubsection{Supresi Artifact dan Pemisahan Background}

Proses Tahapan ini bermaksud untuk menghilangkan objek-objek dalam citra yang mengganggu proses klasifikasi. Proses artifact suppression ini dapat dilihat pada Gambar 7. Adapun tahapan-tahapan dalam operasinya adalah sebagai berikut:

1. Citra mammogram akan dirubah kedalam citra biner dengan proses thresholding $(\mathrm{T}=18)$ seperti terlihat pada Gambar 7b, kemudian semua objek dilabeli menggunakan fungsi bwlabel pada MATLAB. 


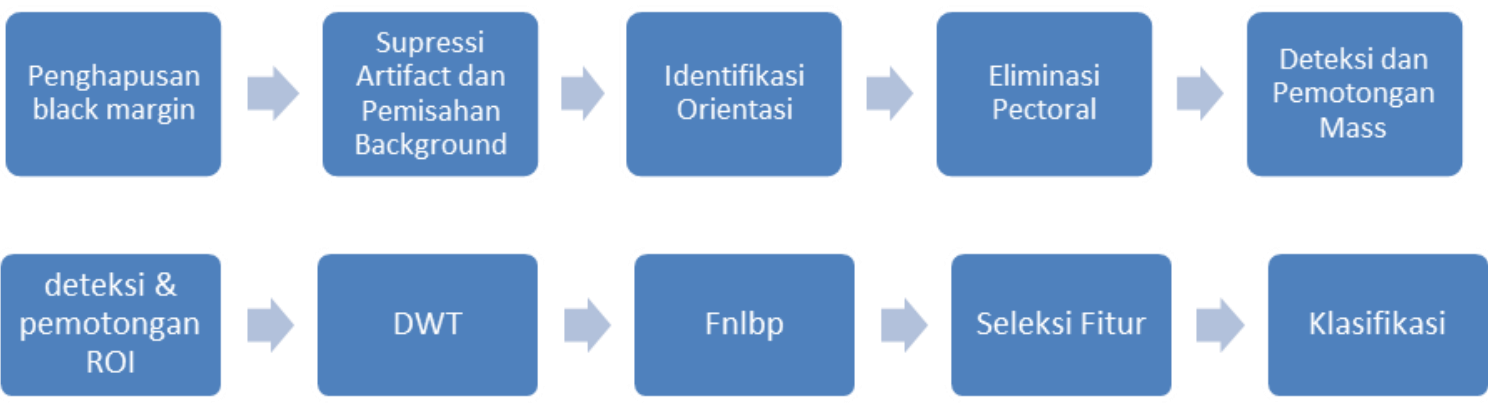

Gambar 5. Alur deteksi dan cropping ROI

2. Area (ukuran sebenarnya dari daerah pixel) dari semua objek pada Gambar 7b akan dikalkulasi menggunakan fungsi regionprops pada MATLAB

3. Dari semua objek biner pada citra mammogram (Gambar 7a), Objek yang memiliki area terbesar (Gambar 7c) pada setiap citra akan dipilih menggunakan fungsi bwareopen pada MATLAB. Proses morphological ini menghapus semua objek biner pada citra mammogram kecuali objek dengan area yang terbesar.

4. Operasi morphological untuk memperkecil distorsi dan menghapus pixel yang terisolasi diaplikasikan ke citra biner mammogram menggunakan fungsi bwmorph pada MATLAB dengan parameter 'clean'.

5. Operasi morphological yang lain diaplikasikan pada citra biner mammogram untuk memperhalus noise yang muncul, operasi yang digunakan adalah fungsi bwmorph pada MATLAB dengan parameter 'majority'.

6. Citra biner mammogram di erosi menggunakan fungsi strel dan imerode, dimana radius dari fungsi strel adalah $\mathrm{R}=5$.

7. Citra biner mammogram di dilasi menggunakan fungsi imdilation pada MATLAB.

8. Lubang pada citra biner mammogram diisi dengan menggunakan fungsi imfill pada MATLAB dengan parameter 'holes'.

9. Hasil citra biner yang dihasilkan dari step 8 dikalikan dengan citra original mammogram setelah penghapusan black margin, fungsi yang digunakan adalah immultiply pada MATLAB dan akan menghasil citra seperti pada Gambar $7 \mathrm{~d}$.
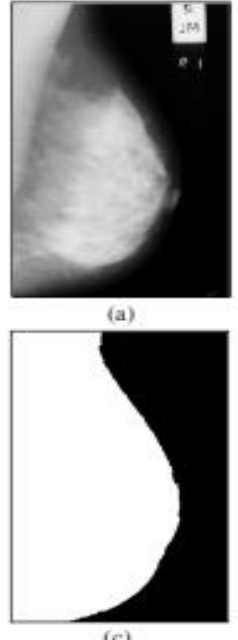

(c)

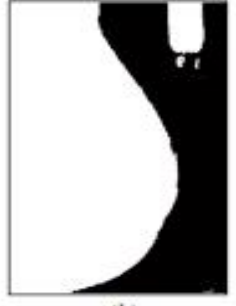

(b)

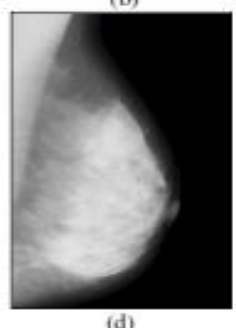

(d)
Gambar 7. Penghapusan objek mengganggu.

\section{III.1.3 Identifikasi Orientasi}

Tahapan orientasi payudara ini berfungsi untuk menentukan letak pectoral muscle dan berfungsi untuk tahapan selanjutnya. Untuk menentukan sebuah citra mammogram memiliki orientasi payudara kekanan atau kekiri maka sebuah citra biner mamogram akan dipotong dari kiri kekanan dan dari atas kebawah sehingga citra biner mammogram akan menjadi empat bagian sama rata yaitu bagian kiri, kanan, atas dan bawah. Kemudian jumlah dari lima nilai kolom pertama dan terkahir pada citra biner yang telah dibagi empat tersebut dikalkulasi, apabila jumlah nilai pixel kolom pertama lebih besar dari 
jumlah nilai pixel pada kolom terakhir maka citra tersebut memiliki orientasi payudara kekanan dan juga sebaliknya. Orientasi citra mammogram ditunjukkan oleh gambar 8 .

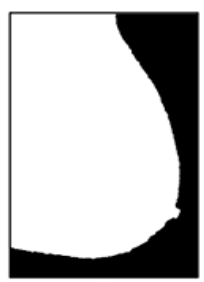

Right orientated

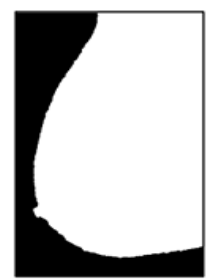

Left orientated

Gambar 8. Orientasi citra mammogram.

\section{III.1.4 Eliminasi Pectoral}

Tahap ini merupakan proses untuk membuang pectoral muscle dari citra mamogram. Pectoral muscle harus dihilangkan karena seringkali memiliki warna pixel yang sama dengan mass kanker payudara sehingga seringkali menurunkan akurasi pada tahap deteksi ROI. Langkah tahap ini dapat dilihat pada Gambar 9. Adapun tahapan penghapusan pectoral muscle ini adalah sebagai berikut:

1. Citra mammogram dibagi menjadi empat kuadran seperti pada tahap identifikasi orientasi (kiriatas,kanan-atas, kiri-bawah, dan kanan-bawah).

2. Jika citra mammogram adalah orientasi kanan maka pectoral pasti berada pada kuadran kiri- atas, sedangkan jika orientasi kiri maka pectoral berada pada kuadran kanan-atas.

3. Kuadran yang terdapat pectoral didalamnya merupakan bagian yang terpenting dan tiga kuadran lainnya dirubah ke warna hitam atau diberi nilai 0 pada pixelnya.

4. Threshold citra mammogram dari tahap 3 dengan nilai $\mathrm{t}=176$ untuk mendapatkan citra biner.

5. Lakukan fungsi invers pada citra biner mammogram.

6. Gunakan fungsi multiply pada citra invers terhadap citra awal mammogram setelah penghapusan artifact.

\section{III.1.5 Deteksi dan Pemotongan Mass (ROI)}

Tahapan deteksi dan pemotonganmerupakan tahap akhir dari tahap deteksi ROI, pada tahap ini dilakukan proses thresholding dan operasi morphologi opening agar menghilangkan bintikbintik selain mass. Setelah mass tersegmentasi maka mass akan dipotong sesuai dengan yang dikehendaki pada penelitian ini akan dipotong ukuran citra sebesar $128 \times 128$ pixel. Adapun tahapan dapat dilihat pada Gambar 10.

\section{III.2 Discrete Wavelet Transform}

Setelah Ekstraksi fitur dari citra mamogram

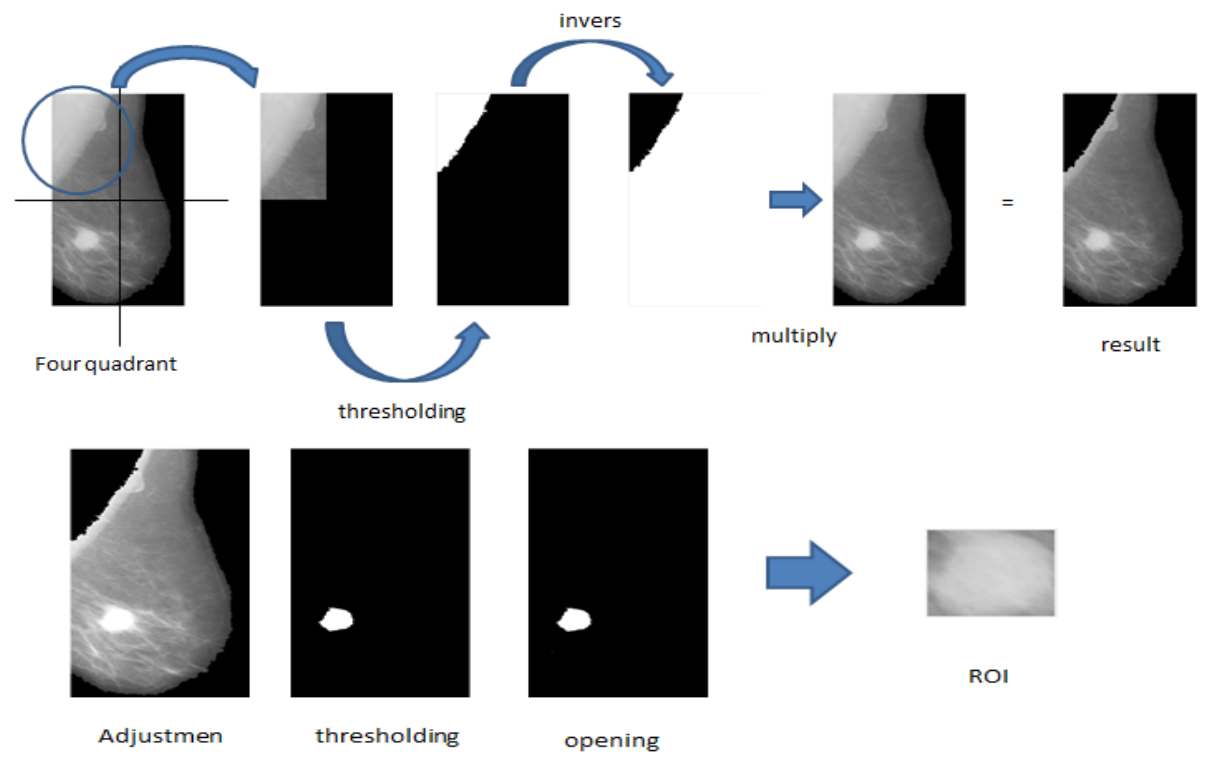

Gambar 10. Tahap pemotongan ROI.

Januar Adi Putra, Nanik Suciati, Arya Yudhi Wijaya

Jurnal Ilmiah Teknologi Informasi Terapan

Volume III, No 2, 15 April 2017 
dilakukan dengan mengkobinasikan dua metode yakni 2D-DWT dan fnLBP. DWT dapat digunakan untuk transformasi citra, proses transformasi wavelet yang dilakukan secara konsep cukup sederhana. Citra semula yang ditransformasi dibagi (didekomposisi) menjadi 4 sub-citra baru untuk menggantikannya. Setiap sub-citra berukuran $1 / 4$ kali dari citra asli. Subcitra pada posisi atas kanan, bawah kiri, dan bawah kanan akan tampak seperti versi kasar dari citra asli karena berisi komponen frekuensi tinggi dari citra asli. Sedangkan untuk 1 sub-citra atas kiri tampak seperti citra asli dan tampak lebih halus (smooth)
Proses thresholding dilakukan pada semua piksel pada box matrik yang ada, sehingga menghasilkan seperti pada gambar 13. Dari Gambar 13 dapat dilihat bahwa pattern yang terbentuk dari proses thresholding adalah 10110000 . Setelah proses thresholding selesai maka langkah selanjutnya adalah melakukan circular pattern. Circular pattern merupakan proses untuk mendapatkan kombinasi susunan pattern dengan cara menggeser bagian kiri ke bagian paling kanan, proses circular pattern dapat
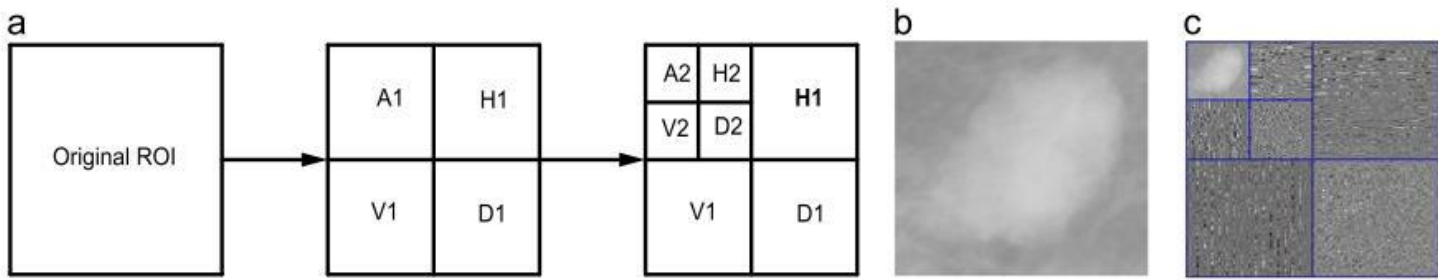

Gambar 11. a) Proses dekomposisi DWT 2 level b) Original ROI c) Hasil DWT terhadap ROI.

karena berisi komponen frekuensi rendah dari citra asli. Discrete wavelete transform yang dilakukan pada penelitian ini adalah level 2 dimana akan menghasilkan 7 sub-citra baru. Tahapan DWT pada penelitian ini dapat dilihat pada Gambar 11.

\section{III.3 Full Neighbor Local Binary Pattern}

Metode ini memiliki perbedaan pada arah dan distribusi relasi spasial dari pixel, dimana perbandingan antar pixel pada proses trhesholding tidak hanya dengan tetangga di bagian kanan saja melainkan dengan semua tetangga yang ada pada sisi horizontal, vertical dan diagonal sehingga metode tersebut disebut full neighbour local binary pattern (fnlbp). Dengan melakukan perbandingan pixel dengan semua tetangga maka proses thresholding akan lebih insensitif terhadap noise yang akan menyebabkan proses thresholding tersebut lebih akurat dan akurasipun akan meningkat. Setelah dilakukan perbandingan maka nilai treshold merupakan nilai mayoritas, jika terbanyak adalah 0 maka threshold adalah 0 , dan sebaliknya. Adapun langkah dari proses perbandingan pada fnLBP ini ditunjukkan pada Gambar 12. dilihat pada Gambar 14 .

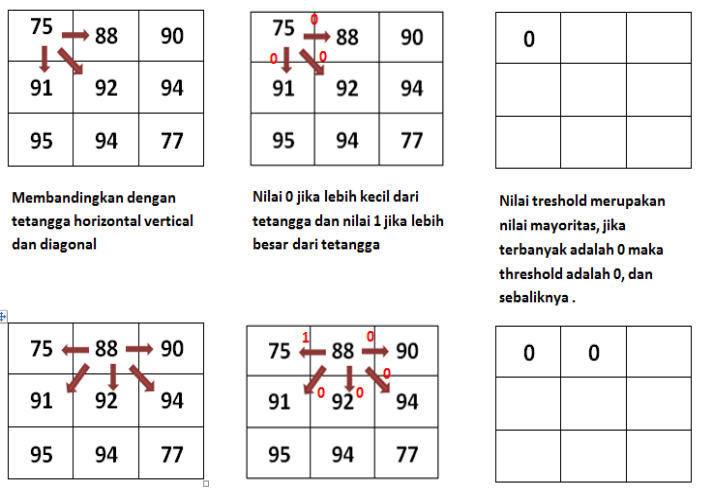

Gambar 12. Contoh proses thresholding pada fnlbp.

\begin{tabular}{|c|c|c|}
\hline 0 & 0 & 0 \\
\hline 0 & & 1 \\
\hline 1 & 1 & 0 \\
\hline
\end{tabular}

Gambar 13. hasil akhir proses thresholding. 
Proses circular pattern dilakukan terus hingga posisi kembali seperti pattern awal, proses ini akan menghasilkan 8 kombinasi pattern baru. Setelah didapat kombinasi-kombinasi yang lain maka langkah terkahir adalah mengalikan dengan bobot

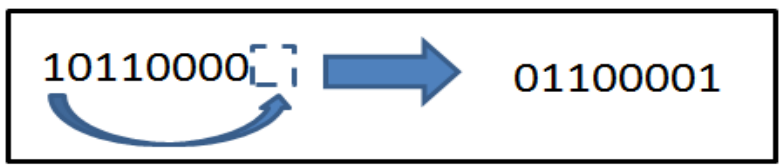

Gambar 14. Proses circular pattern.

seperti pada LBP tradisional. Histogram akhir merupakan nilai terkecil dari hasil perkalian tersebut. Contoh kombinasi pattern yang didapat dapat dilihat pada Gambar 15.

\section{III.4 Seleksi Fitur}

Pada penelitian ini dilakukan seleksi fitur menggunakan metode statistika yaitu two sample ttest dan f-test. T-test dikenal dengan uji parsial, yaitu untuk menguji bagaimana pengaruh masing-masing variabel bebasnya secara sendiri-sendiri terhadap variabel terikatnya. Uji ini dapat dilakukan dengan mambandingkan $t$ hitung dengan $t$ tabel atau dengan melihat kolom signifikansi pada masing-masing $\mathrm{t}$ hitung. F-test dikenal dengan Uji serentak atau uji Model/Uji Anova, yaitu uji untuk melihat bagaimanakah pengaruh semua variabel bebasnya secara bersama-sama terhadap variabel terikatnya. $T$ test ataupun $f$-test berfungsi untuk menghasilkan hipotesa apakah sebuah fitur suatu kelas tersebut significant terhadap fitur yang sama pada kelas lainnya. Jika model signifikan maka model tidak bisa digunakan untuk klasifikasi, sebaliknya jika non/tidak signifikan maka model regresi bisa digunakan untuk proses klasifikasi. Untuk algoritma t-test dan f-test dapat dilihat pada Gambar 16.

\section{Hasil dan PEMbahasan}

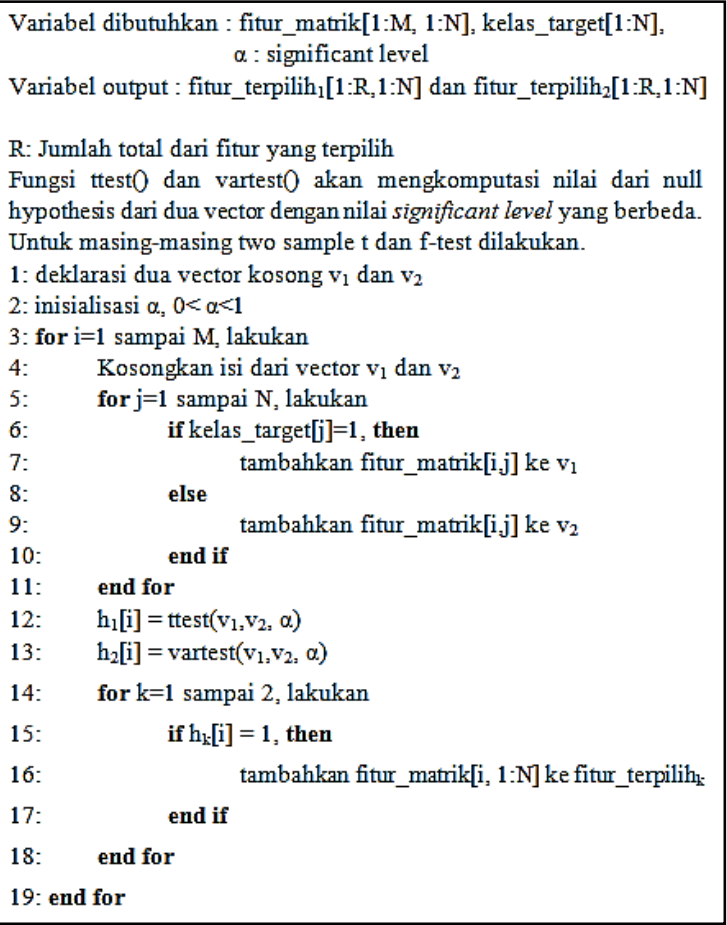

Dalam bab ini akan dipaparkan hasil serta pembahasan penelitian yang telah dilakukan.

\section{IV.1 Dataset Uji Coba}

Data yang digunakan pada penelitian ini adalah citra yang diperoleh dari database Mammographic Image Analysis Society (MIAS) dan DDSM. Data MIAS didapat melalui website http://peipa.essex.ac.uk/pix/mias , sedangkan data DDSM didapat dari http://marathon.csee.usf.edu/ Mammography/Database.html. Dengan jumlah data citra mammogram adalah 317 citra, dengan 208 citra normal dan 109 citra abnormal.

\section{IV.2 Uji Coba Invarian Rotasi}

Uji coba ini dilakukan untuk melihat apakah metode usulan fnlbp mengatasi masalah dari lbp

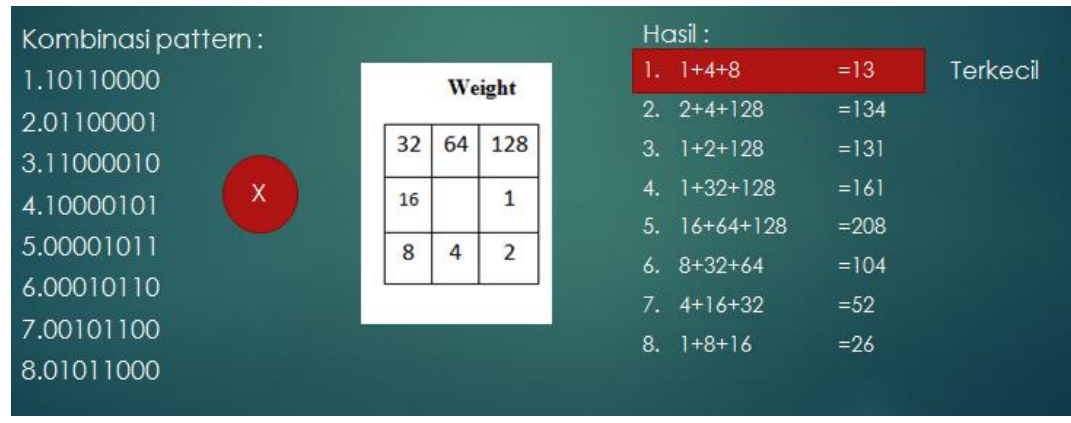


tradisional yakni varian terhadap rotasi. Varian terhadap rotasi akan menyebabkan kesulitan pada saat ekstraksi fitur hal ini dikarenakan semua gambar harus memiliki posisi kemiringan citra yang sama antar satu dengan yang lain, hal ini tentunya akan mengkonsumsi waktu pengerjaan yang lebih lama. Uji coba dilakukan dengan menggunakan dua citra yang sama tetapi dengan tingkat rotasi yang berbeda seperti terlihat pada Gambar 17a dan Gambar 17b.

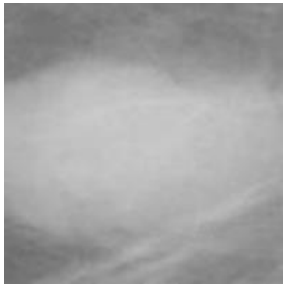

a

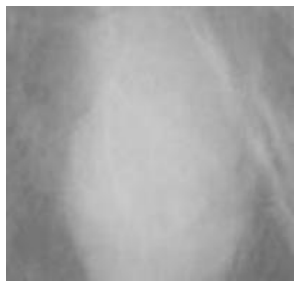

b
Gambar 17. Citra Mammogram . a)Awal. b)rotasi.

Hasil perbandingan histogram menggunakan metode ektraksi lbp dapat dilihat pada Gambar 18. Terlihat bahwa histogram hasil lbp berbeda antara satu dengan yang lain, gambar kiri pada Gambar 18 adalah histogram citra mammogram awal sedangkan gambar kanan merupakan histogram citra mammogram setelah dirotasi. Perbedaan yang terjadi pada hasil histogram mengindikasikan bahwa metode lbp varian terhadap rotasi, sehingga metode lbp tidak cocok untuk digunakan pada dataset citra yang berukuran besar dan memiliki tingkat rotasi yang berbeda-beda.

Hasil perbandingan histogram menggunakan metode ektraksi fnlbp dapat dilihat pada Gambar 19. Terlihat bahwa histogram hasil fnlbp sama persis antara satu dengan yang lain, gambar kiri pada Gambar 19 adalah histogram citra mammogram awal sedangkan gambar kanan merupakan histogram citra mammogram setelah dirotasi. Hasil histogram yang sama pada hasil ekstraksi menggunakan fnlbp mengindikasikan bahwa metode fnlbp invarian terhadap rotasi, sehingga rotasi yang berbeda-beda tidak akan berpengaruh terhadap hasil histogram. Metode yang invarian terhadap rotasi cocok untuk digunakan pada dataset citra yang memiliki tingkat rotasi yang berbeda-beda sehingga akan menghemat waktu penelitian.
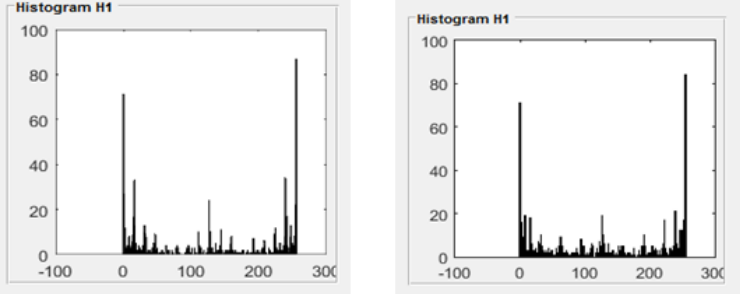

Gambar 18. Hasil Histogram lbp.
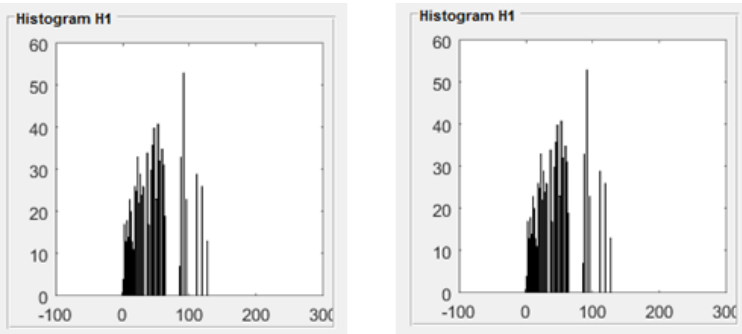

Gambar 19. Hasil Histogram fnlbp.

\section{IV.3 Uji Coba Seleksi Fitur}

Seleksi fitur digunakan untuk mengurangi dimensi data dan fitur-fitur yang tidak relevan. Seleksi fitur juga digunakan untuk meningkatkan efektifitas dan efisiensi kinerja dari algoritma klasifikasi. Metode seleksi fitur yang digunakan adalah f-test dan t-test dan parameter yang berpengaruh pada dua metode tersebut adalah significant level. Uji coba juga dilakukan pada tahapan seleksi fitur dengan cara merubah-rubah nilai parameter significant level, hal ini dimaksudkan untuk mengetahui hubungan variabel significant level dengan hasil seleksi fitur yang ada. Nilai significant level yang menjadi parameter uji adalah $0.1,0.3,0.5$, $0.7,0.9$.

Adapun f-test dan t-test akan dilakukan dan dibandingkan pada dataset hasil dari ektraksi fitur metode penggabungan wavelet dan lbp dengan wavelet dan fnlbp. Setiap satu citra mammogram akan menghasilkan 7 sub citra hasil dekomposisi discrete wavelet transform dan yang akan digunakan untuk proses ektraksi fitur adalah 6 sub citra yakni dekomposisi horizontal level 1 dan 2, dekomposisi vertical level 1 dan 2 , serta dekomposisi diagonal level 1 dan 2. Satu buah subcitra akan menghasilkan satu buah histogram hasil ektraksi fitur lbp ataupun fnlbp, sedangkan satu histogram terdiri dari 256 fitur sehingga 6 sub citra akan menghasilkan 1536 fitur. Simulasi ektraksi data citra mammogram hingga 
menjadi fitur dapat dilihat pada Gambar 20 dan hasil pengujian seleksi fitur dapat dilihat pada Tabel 1 .

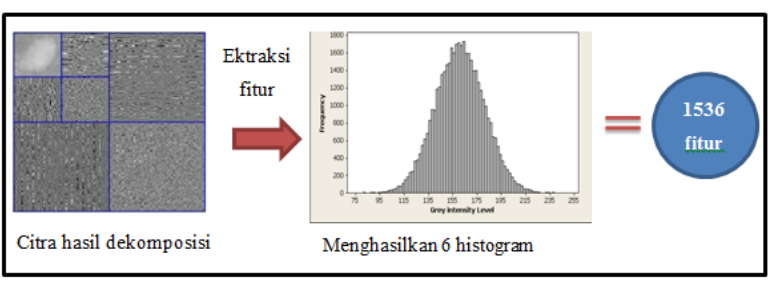

Gambar 20. Simulasi ektraksi dan seleksi fitur.

Tabel 1. Hasil Seleksi Fitur.

\begin{tabular}{lcccc}
\hline \hline $\begin{array}{c}\text { Significant } \\
\text { level }\end{array}$ & \multicolumn{2}{c}{$\begin{array}{c}\text { Jumlah Fitur } \\
\text { LBP }(\mathbf{R})\end{array}$} & \multicolumn{2}{c}{$\begin{array}{c}\text { Jumlah Fitur } \\
\text { FNLBP }(\mathbf{R})\end{array}$} \\
\cline { 2 - 3 } & T-test & F-test & T-test & F-test \\
\hline \hline 0.1 & & & & \\
0.3 & 158 & 453 & 175 & 174 \\
0.5 & 1173 & 175 & 188 & 192 \\
0.7 & 1330 & 1226 & 206 & 211 \\
0.9 & 1478 & 1443 & 213 & 216 \\
\hline \hline
\end{tabular}

Dapat terlihat dalam Tabel 1 jumlah fitur terkecil dihasilkan oleh metode seleksi fitur F-test pada data hasil ektraksi menggunakan fnlbp dengan nilai significant level 0.1 yakni 174 , sedangkan jumlah fitur terbanyak dihasilkan oleh metode seleksi fitur T-test pada data hasil ektraksi menggunakan lbp dengan nilai significant level 0.9 yakni 1478 .
Berdasarkan hasil yang didapat seperti pada Tabel 1 juga dapat disimpulkan bahwa semakin tinggi nilai significant level maka fitur yang terseleksi akan semakin kecil sehingga hasil akhir fitur akan mendekakti fitur awal sebelum dilakukan seleksi fitur, begitu pula sebaliknya semakin rendah nilai significant level maka fitur yang terseleksi akan semakin banyak dan menghasilkan fitur yang dianggap independent lebih sedikit. Penyebab significant level berbanding terbalik dengan hasil seleksi fitur adalah karena significant level digunakan sebagai pembanding untuk menentukan sebuah fitur dianggap independent atau tidak sehingga jika nilai significant level lebih besar maka peluang sebuah fitur dianggap independent akan semakin kecil.

Dari Tabel 1 juga dapat terlihat bahwa hasil dataset hasil ekstraksi fitur fnlbp akan memiliki fitur lebih sedikit setelah di seleksi daripada dataset hasil ektraksi fitur lbp, hal ini disebabkan karena persebaran histogram hasil ektraksi fitur local binary pattern memiliki variasi bit histogram yang terisi lebih tersebar dan banyak daripada histogram hasil ekstraksi fitur menggunakan fnlbp. Penjelasan dan perbandingan tentang analisa histogram lbp dan fnlbp telah dijelaskan pada sub bab sebelumnya yakni subbab ektraksi fitur.

\section{IV.4 Uji Coba Klasifikasi}

Pengujian dilakukan dengan membandingkan metode fnlbp dan lbp tradisional dengan menggunakan discrete wavelet transform, tanpa discrete wavelet transform serta pada koefisien level

Tabel 2. Tabel Performa DWT+fnlbp.

\begin{tabular}{cccccccccc}
\hline \hline Uji & $\begin{array}{c}\text { Significant } \\
\text { Level }\end{array}$ & R & TP & TN & FP & FN & Sensitivity & Specifisity & Akurasi (\%) \\
\hline \hline \multirow{5}{*}{ T-test } & 0.9 & 213 & 76 & 145 & 0 & 0 & 1.00 & 1.00 & $\mathbf{1 0 0 . 0 0}$ \\
& 0.7 & 206 & 69 & 145 & 7 & 0 & 1.00 & 0.95 & 96.83 \\
& 0.5 & 197 & 76 & 145 & 0 & 0 & 1.00 & 1.00 & $\mathbf{1 0 0 . 0 0}$ \\
& 0.3 & 188 & 74 & 145 & 2 & 0 & 1.00 & 0.98 & 99.09 \\
\hline \hline \multirow{3}{*}{ F-test } & 0.1 & 175 & 76 & 145 & 0 & 0 & 1.00 & 1.00 & $\mathbf{1 0 0 . 0 0}$ \\
& 0.9 & 216 & 75 & 145 & 1 & 0 & 1.00 & 0.99 & 99.54 \\
& 0.7 & 211 & 76 & 145 & 0 & 0 & 1.00 & 1.00 & $\mathbf{1 0 0 . 0 0}$ \\
& 0.5 & 207 & 55 & 145 & 21 & 0 & 1.00 & 0.87 & 90.49 \\
\hline \hline
\end{tabular}


Tabel 3. Tabel Performa DWT+lbp.

\begin{tabular}{cccccccccc}
\hline \hline Uji & $\begin{array}{c}\text { Significant } \\
\text { Level }\end{array}$ & $\mathbf{R}$ & TP & TN & FP & FN & Sensitivity & Specifisity & Akurasi (\%) \\
\hline \hline \multirow{5}{*}{ T-test } & 0.9 & 1478 & 72 & 145 & 4 & 0 & 1.00 & 0.97 & 98.19 \\
& 0.7 & 1330 & 72 & 145 & 4 & 0 & 1.00 & 0.97 & 98.19 \\
& 0.5 & 1173 & 57 & 145 & 19 & 0 & 1.00 & 0.88 & 91.40 \\
& 0.3 & 1010 & 47 & 145 & 29 & 0 & 1.00 & 0.83 & 86.87 \\
\hline \hline \multirow{3}{*}{ F-test } & 0.1 & 758 & 75 & 145 & 1 & 0 & 1.00 & 0.99 & $\mathbf{9 9 . 5 4}$ \\
& 0.9 & 1443 & 32 & 145 & 44 & 0 & 1.00 & 0.76 & 80.09 \\
& 0.7 & 1226 & 57 & 145 & 19 & 0 & 1.00 & 0.88 & 91.40 \\
& 0.5 & 1021 & 76 & 145 & 0 & 0 & 1.00 & 1.00 & $\mathbf{1 0 0 . 0 0}$ \\
\hline \hline
\end{tabular}

satu dan duanya saja. Performa metode dapat dilihat pada Tabel 2 sampai dengan Tabel 5.

Dapat dilihat pada Tabel 2 performa kombinasi discrete wavelet transform dan full neighbour local binary pattern menghasilkan akurasi yang sempurna yakni $100 \%$ pada seleksi fitur t-test dengan nilai significant level 0.9, 0.5 dan 0.1. Pada ujicoba menggunakan seleksi fitur menggunakan f-test kombinasi discrete wavelet transform dan full neighbour local binary pattern mendapatkan akurasi sempurna hanya pada nilai significant level 0.7 .

Untuk nilai sensitivitas kombinasi ini menghasilkan nilai sempurna pada semua rangkaian ujicoba sedangkan untuk spesifisitas nilai sempurna didapat pada saat akurasi juga mendapat nilai sempurna yakni pada seleksi fitur t-test dengan nilai significant level 0.9, 0.5 dan 0.1 , serta seleksi fitur ftest dengan significant level 0.7. Nilai akurasi terendah untuk kombinasi discrete wavelet transform dan full neighbour local binary pattern didapat pada saat digunakan metode seleksi fitur f-test dengan nilai significant level 0.5 yakni $90.49 \%$ sedangkan untuk metode seleksi fitur t-test akurasi terendah didapat pada significant level 0.7. Dari tabel 2 juga didapat fakta bahwa nilai spesifisitas berbanding lurus dengan akurasi sedangkan sensitivitas tidak.

Untuk kombinasi discrete wavelet transform dan local binary pattern dapat terlihat performa pada Tabel 3 menghasilkan akurasi yang sempurna yakni $100 \%$ pada seleksi fitur f-test dengan nilai significant level 0.5. Pada ujicoba menggunakan seleksi fitur menggunakan t-test kombinasi discrete wavelet transform dan local binary pattern tidak terdapat akurasi sempurna nilai tertinggi hanya pada nilai significant level 0.1 yakni dengan akurasi 99.54. Untuk nilai sensitivitas kombinasi ini menghasilkan nilai sempurna pada semua rangkaian ujicoba sedangkan untuk spesifisitas nilai sempurna didapat pada saat akurasi juga mendapat nilai sempurna yakni pada seleksi fitur t-test dengan nilai significant level 0.1 dengan nilai spesifisitas 0.99 , serta seleksi fitur ftest dengan significant level 0.5 dengan nilai spesifisitas 1.00 .

Nilai akurasi terendah untuk kombinasi discrete wavelet transform dan local binary pattern didapat pada saat digunakan metode seleksi fitur f-test dengan nilai significant level 0.9 yakni $80.09 \%$ sedangkan untuk metode seleksi fitur t-test akurasi terendah didapat pada significant level 0.3. Dari tabel 2 dan tabel 3 didapat fakta bahwa metode usulan mendapatkan rata-rata akurasi yang lebih baik daripada metode kombinasi discrete wavelet transform dan local binary pattern tradisional, hal ini berarti kombinasi discrete wavelet transform dan full neighbour local binary pattern lebih cocok untuk digunakan pada klasifikasi mammogram. Setelah dilakukan ujicoba untuk mendapatkan dan membandingkan performa dari metode usulan yakni kombinasi discrete wavelet transform dan full neighbour local binary pattern dengan kombinasi discrete wavelet transform dan local binary pattern tradisional, langkah selanjutnya adalah menguji metode terhadap citra mammogram tanpa dilakukan 
dekomposisi citra menggunakan discrete wavelet transform terlebih dahulu. Untuk data latih dan data training yang digunakan adalah sama dengan data ujicoba sebelumnya dengan pembagian yang sama
Untuk metode tradisional local binary pattern dapat terlihat performa pada Tabel 5 menghasilkan akurasi yang tertinggi yakni $93.21 \%$ pada seleksi fitur f-test dengan nilai significant level 0.1. Pada

Tabel 4. Tabel Performa fnlbp.

\begin{tabular}{cccccccccc}
\hline \hline Uji & $\begin{array}{c}\text { Significant } \\
\text { Level }\end{array}$ & R & TP & TN & FP & FN & Sensitivity & Specifisity & Akurasi (\%) \\
\hline \hline \multirow{5}{*}{ T-test } & 0.9 & 32 & 72 & 145 & 4 & 0 & 1.00 & 0.97 & 98.19 \\
& 0.7 & 34 & 75 & 145 & 1 & 0 & 1.00 & 0.99 & 99.54 \\
& 0.5 & 34 & 73 & 145 & 3 & 0 & 1.00 & 0.97 & 98.64 \\
& 0.3 & 34 & 73 & 145 & 3 & 0 & 1.00 & 0.97 & 98.64 \\
\hline \hline \multirow{5}{*}{ F-test } & 0.1 & 34 & 76 & 145 & 0 & 0 & 1.00 & 1.00 & $\mathbf{1 0 0 . 0 0}$ \\
& 0.9 & 36 & 75 & 145 & 1 & 0 & 1.00 & 0.99 & $\mathbf{9 9 . 5 4}$ \\
& 0.7 & 36 & 57 & 145 & 19 & 0 & 1.00 & 0.88 & 91.40 \\
& 0.5 & 36 & 73 & 145 & 3 & 0 & 1.00 & 0.97 & 98.64 \\
\hline \hline
\end{tabular}

juga yakni $70 \%$ data training dan $30 \%$ data testing.

Dapat dilihat pada Tabel 4 performa metode usulan full neighbour local binary pattern menghasilkan akurasi yang sempurna yakni $100 \%$ pada seleksi fitur t-test dengan nilai significant 0.1 . Pada ujicoba menggunakan seleksi fitur menggunakan f-test full neighbour local binary pattern mendapatkan akurasi tertinggi pada nilai

significant level 0.9 yakni $99.54 \%$. Untuk nilai sensitivitas metode usulan ini menghasilkan nilai sempurna pada semua rangkaian ujicoba sedangkan untuk spesifisitas nilai sempurna didapat pada saat akurasi juga mendapat nilai sempurna yakni pada seleksi fitur t-test dengan nilai significant level 0.1 , serta seleksi fitur f-test dengan significant level 0.9 mendapat nilai spesifisitas 0.99. Nilai akurasi terendah untuk metode usulan full neighbour local binary pattern didapat pada saat digunakan metode seleksi fitur f-test dengan nilai significant level 0.7 yakni $91.40 \%$ sedangkan untuk metode seleksi fitur ttest akurasi terendah didapat pada significant level 0.5 dan 0.3 yakni $98.64 \%$. ujicoba menggunakan seleksi fitur menggunakan ttest metode tradisional local binary pattern tidak terdapat akurasi sempurna, nilai tertinggi hanya pada nilai significant level 0.9 yakni dengan akurasi 92.76. Untuk nilai sensitivitas kombinasi ini menghasilkan nilai sempurna pada semua rangkaian ujicoba sedangkan untuk spesifisitas nilai sempurna didapat pada saat akurasi juga mendapat nilai sempurna yakni pada seleksi fitur t-test dengan nilai significant level 0.9 dengan nilai spesifisitas 0.90 , serta seleksi fitur ftest dengan significant level 0.1 dengan nilai spesifisitas 0.90. Nilai akurasi terendah untuk local binary pattern didapat pada saat digunakan metode seleksi fitur t-test dengan nilai significant level 0.3 yakni $74.20 \%$. Dari tabel 4 dan tabel 5 didapat fakta bahwa metode usulan tetap mendapatkan rata-rata akurasi yang lebih baik daripada metode local binary pattern tradisional meskipun tanpa dilakukan dekomposisi discrete wavelet transform pada citra mammogram sebelumnya 
Tabel 5. Tabel Performa lbp.

\begin{tabular}{cccccccccc}
\hline \hline Uji & $\begin{array}{c}\text { Significant } \\
\text { Level }\end{array}$ & $\mathbf{R}$ & TP & TN & FP & FN & Sensitivity & Specifisity & Akurasi (\%) \\
\hline \hline \multirow{5}{*}{ T-test } & 0.9 & 250 & 60 & 145 & 16 & 0 & 1.00 & 0.90 & $\mathbf{9 2 . 7 6}$ \\
& 0.7 & 238 & 56 & 145 & 20 & 0 & 1.00 & 0.87 & 90.95 \\
& 0.5 & 223 & 54 & 145 & 22 & 0 & 1.00 & 0.86 & 90.04 \\
& 0.3 & 205 & 19 & 145 & 57 & 0 & 1.00 & 0.71 & 74.20 \\
\hline \hline \multirow{5}{*}{ F-test } & 0.1 & 182 & 25 & 145 & 51 & 0 & 1.00 & 0.73 & 76.92 \\
& 0.9 & 240 & 59 & 145 & 17 & 0 & 1.00 & 0.89 & 92.30 \\
& 0.7 & 219 & 57 & 145 & 19 & 0 & 1.00 & 0.88 & 91.40 \\
& 0.5 & 188 & 59 & 145 & 17 & 0 & 1.00 & 0.89 & 92.30 \\
\hline \hline
\end{tabular}

\section{KeSIMPUlan}

Metode Berdasarkan aplikasi yang telah dibuat dan hasil yang didapat dari serangkaian uji coba yang telah dilakukan terhadap metode usulan full neighbour local binary pattern (fnlbp) dan local binary pattern (lbp) tradisional, maka dapat ditarik kesimpulan atas penelitian ini sebagai berikut:

1. Metode usulan mendapatkan rata-rata akurasi yang lebih baik daripada metode local binary pattern tradisional baik yang dikombinasi dengan discrete wavelet transform ataupun tidak.

2. Pada histogram hasil ektraksi $l b p$ dapat terlihat bahwa kecenderungan nilai bit histogram yang tinggi adalah 0 dan 255 sedangkan pada histogram hasil fnlbp persebaran bit tinggi cukup merata, hal ini mebuktikan metode usulan fnlbp yang membandingkan semua tetangga dengan sisi vertikal,horizontal maupun diagonal tidak sensitif terhadap noise.

3. Hasil ujicoba pada dua citra yang dirotasi menghasilkan histogram yang sama pada hasil ekstraksi menggunakan fnlbp mengindikasikan bahwa metode fnlbp invarian terhadap rotasi, sehingga rotasi yang berbeda-beda tidak akan berpengaruh terhadap hasil histogram

4. Dataset hasil ekstraksi fitur fnlbp akan memiliki fitur lebih sedikit setelah di seleksi daripada dataset hasil ektraksi fitur $l b p$, hal ini disebabkan karena persebaran histogram hasil ektraksi fitur $l b p$ memiliki variasi bit histogram yang terisi lebih tersebar dan banyak daripada histogram hasil ekstraksi fitur menggunakan fnlbp.

5. Semakin tinggi nilai significant level maka fitur yang terseleksi akan semakin kecil sehingga hasil akhir fitur akan mendekakti fitur awal sebelum dilakukan seleksi fitur, begitu pula sebaliknya semakin rendah nilai significant level maka fitur yang terseleksi akan semakin banyak dan menghasilkan fitur yang dianggap independent lebih sedikit

\section{REFERENSI}

A. Dhawan et al (1996), Analysis of mammographic microcalcifications using greylevel image structure features, IEEE Trans. Med. Imaging 15 (3) 246-259

Buciu, A. Gacsadi (2011), Directional features for automatic tumor classification of mammogram images, Biomed. Signal Process. Control 6 (4) 370-378.

E.A. Rashed, I.A. Ismail, S.I. Zaki (2007), Multiresolution mammogram analysis in multilevel decomposition, Pattern Recognit. Lett. 28 (2) 286-292. 
F.Suhandi Krisna (2009), Prediksi Harga Saham dengan Pendekatan Artificial Neural Network menggunakan Algoritma Backpropagation.

Jianguo Zhang, Kai-Kuang Ma, Meng Hwa Er,Vincent Chong, "Tumor segmentation from magnetic resonance imaging by learning via one-class support vector machine".

Kaya.Y, Ertugrul.O.F, Taekin.R (2015), Two Novel Local Binary Pattern Descriptor for Texture Analysis, Applied Soft Computing 34 728-735

Kusumadewi, Sri, 2004, "Membangun Jaringan Syaraf Tiruan Menggunakan MATLAB \& EXCEL LINK”, Graha Ilmu, Yogyakarta

Matei Mancas, Bernard Gosselin, "Fuzzy Tumor Segmentation based on Iterative Watersheds".

Mayer., Welsh dan Kowalak, (2011:13). Buku Ajar Patofisiologi. Jakarta: EGC.

Nugroho, (2011:122). Asuhan Keperawatan. Yogjakarta: Nuha Medika.

Putra, Darma, (2010) 'Pengolahan Citra Digital'. Yogyakarta, Penerbit Andi

R. Adollah, M.Y. Mashor, N.F. Mohd Nasir, H. Rosline, H. Mahsin, H. Adilah (2008), "Blood Cell Image Segmentation: A Review",Biomed, Proceedings 21, pp. 141-144, 2008

Sanae.B, Mounir A.K, Youssef.F (2015), A Hybrid Feature Extraction Scheme Based on DWT and Uniform LBP for Digital Mammograms Classification. International Review on Computer and Software.

Shan Shen, William Sandham,Malcolm Granat, Annette Sterr (2005), "MRI Fuzzy Segmentation of Brain Tissue Using Neighborhood Attraction With Neural-Network Optimization", IEEE transactions on information technology in biomedicine, vol. 9, no. 3.

Santoso, Alb. Joko ( 2011), Wavelet,Diktat Kuliah Pengolahan Citra, Magister Teknik Informatika, Universitas Atmajaya Yogyakarta

S. Liu, C.F. Babbs, E.J. Delp (2001), Multiresolution detection of spiculated lesions in digital mammograms, IEEE Trans. Image Process. 10 (6) 874-884.

T. Ahonen, A. Hadid dan M. Pietikainen (2004), "Face Recognition with Local Binary Patterns," Machine Vision Group, Infotech Oulu.

Uyun, S. \& Harjoko, A (2011). Deteksi Abnormalitas Pada Citra Mammogram dengan Gray-Level Co-Occurrence Matrix 